\title{
ATRIAL MYXOMA, THE SUBSTRATE OF ATRIAL FIBRILLATION, ACCOMPANIED BY THROMBOCYTOPENIA - PERSPECTIVES FOR THE ANTICOAGULATION OPTION AND A FUTURE SURGERY INTERVENTION
}

\author{
Mădălina Moisi, Adriana Ardelean, Larisa Roşan, Cosmin Mihai Vesa, Alexandra Cozma, \\ Livia Mihelea, Marius Rus, Mircea Ioachim Popescu \\ Spitalul Clinic Judeţean de Urgenţă din Oradea \\ Adresă de corespondenţă: mada_vidican@yahoo.ro
}

\begin{abstract}
Atrial myxomas are common benign tumors localized in the left atrium (85\%). The diagnosis is often made during routine examination due to the fact that they are usually asymptomatic. Sometimes the complications of these benign tumors, consisting in embolic events and obstructive valvular disfunction, may be alarm signs that reveal the underlying pathological condition.

We report the case of a 63-years-old female presenting with non-specific symptoms, the echocardiography was the one that showed the left atrial mass. The particularity that made this case special was the fact that the anticoagulation indication for the atrial fibrillation discovered on the ECG was correlated with the presence of the thrombocytopenia, so the final decision was to postpone it till the surgery. After the removal of the atrial tumor the sinusal rhythm was restored and the combination of beta-blockers and antiplatelet was the best therapeutic choice.
\end{abstract}

Keywords: atrial myxomas, echocardiography, atrial fibrillation.

\section{Rezumat}

Mixoamele atriale sunt tumori benigne localizate cel mai frecvent în atriul stâng (85\%). Diagnosticul se face adesea cu ocazia examinărilor de rutină, ca urmare a faptului că sunt, de obicei, asimptomatice. Uneori complicațiile acestor tumori benigne, care se manifestă în evenimente embolice și disfuncție valvulară obstructivă, pot fi semnele de alarmă care relevă patologia subiacentă.

Prezentăm cazul unei femei de 63 de ani care prezintă simptome nespecifice, ecocardiografia fiind cea care descoperă formaţiunea tumorală din atriul stâng. Particularitatea care a făcut acest caz special a fost faptul că indicația anticoagulantă pentru fibrilația atrială descoperită pe ECG a fost condiţionată de prezența trombocitopeniei, decizia finală fiind temporizarea indicaţiei până la excizia tumorii atriale stângi. După intervenţia chirurgicală, ritmul sinusal a fost restabilit, iar combinația de beta-blocante și antiagregante plachetare a fost cea mai bună alegere terapeutică.

Cuvinte cheie: mixom atrial, ecocardiografie, fibrilație atrială. 


\section{Introduction}

Atrial myxomas are common cardiac tumors which are usually attached to the interatrial septum. They are often undiagnosed or accidentally discovered at routine echocardiography. The rare scenario consists in the possibility of embolization in the systemic circulation of small pieces from the tumor, or the hypothesis of obstruction in the pathway of ejection of the left atrium with overload of the pulmonary circulation ${ }^{(1)}$.

We report the case of a 63-years-old female presenting with shortness of breathing, palpitations with slow onset, with worsening of these accuses a few days before the admission. From the medical history we can assess liver cirrhosis secondary to virus $\mathrm{C}$ infection.

The clinical examination revealed arrhythmic cardiac beats, with 100 beats/minute, the recorded blood pressure was 140/80 $\mathrm{mmHg}$, with a breathing rate of 16 breaths/min, with a $92 \%$ oxygen saturation, hepatomegaly (increased liver span). We performed an electrocardiogram which showed the atrial fibrillation with a 100 beats/minute ventricular rate and no ischemic signs. The laboratory findings expressed increased total bilirubin and uric acid, moderate thrombocytopenia, hypokalemia, with negative $B$ surface antigen nor C antibodies, normal alkaline phosphatase, cholinesterase. We also thought a blood smear would be useful to see if there isn't a hematological cause for the thrombocyto-penia, but no notifiable changes were found with this examination. The next step was the protein electrophoresis to check the liver status since the other findings didn't reveal the active status of a liver damage. Hence, the electrophoresis was atypical for presumed active liver cirrhosis, with normal albumins, beta globulins and mild hypergammaglobu-linemia.

The next step was the 2-D echocardiography which surprisingly revealed a $2,42 / 3 \mathrm{~cm}$ mobile mass in the left atrium, with a narrow stalk, attached of the interatrial septum, enlarged left atrium (42 $\mathrm{mm}$ ), increased aortic velocity (appreciated $\mathrm{V}$ max of Aorta $2,2 \mathrm{~m} / \mathrm{s}$ ), assuming an aortic sclerosis, with preserved ejection fraction. Threedimensional TEE showed a more definite connection with a long stalk between the mass and atrial septum and characteristic tumor-like movement along with cardiac cycle. The left atrial appendage examination didn't trace any masses.

As the surgery and anticoagulation indication is reliable, we wanted to elucidate the liver issue, so we requested an abdominal echocardiography which expressed an increased liver diameter, with normal echogenicity and very small modification of the liver surface, no nodules description splenomegaly with $17 / 6 \mathrm{~cm}$ diameter and 
homogenous consistence. The hematologist opinion was to delay the initiation of anticoagulation. The CHA2DS-VASC2 score result was 1 expressing ,low", but still remains the possibility of antiplatelet therapy or even oral anticoagulation, and the HASBLED score assessment was 1.

The treatment consisted in cardiac tonics, intravenous diuretics, beta blockers, potassium with favorable evolution, with diminished shortness of breathing.

\section{Discussions}

Cardiac myxoma represents a single mass fixed by a pedicle in the interatrial septum, near the oval foramen. Despite the fact that they are benign tumors the surgical intervention is demanded because the risk of recurrence is remarkable.

Also the tumor excision solves the two major complications: preventing the sudden death due to the tumor obstruction in the atrioventricular orifice and reduce the possibility of embolic events ${ }^{(3)}$. Cardiac myxomas can represent an isolated pathological condition or a part of the myxomas syndromes. The myxoma syndrome includes atrial benign tumors and pigmented spots on the skin, known as lentigines. LAMB, NAME and Carney syndrome were described, the common features of them were the left atrial mass and different dermatological lesions ${ }^{(2)}$.

The differential diagnosis is very important and atrial myxomas should be distinguished from atrial thrombi, since the treatment of these diseases is distinct. The clinical context expressing the atrial fibrillation with uncertain onset and no previous anticoagulation therapy, left atrial enlargement predisposing to blood clotting could reflect the possibility of thrombotic etiology of the large atrial

\begin{tabular}{|c|c|c|}
\hline \multicolumn{3}{|c|}{ BIOCHEMISTRY } \\
\hline Sodium & 139 & $136-145 / \mathrm{mmol} / \mathrm{l}$ \\
\hline Chloride & 98 & $98-107 / \mathrm{mmol} / \mathrm{l}$ \\
\hline Potassium & 3.4 & $3.5-5.1 / \mathrm{mmol} / \mathrm{l}$ \\
\hline Alkaline phosphatase & 51 & $40-150 / U / L$ \\
\hline $\mathrm{ALT}(\mathrm{GPT})$ & 20 & $0-55 / \mathrm{U} / \mathrm{L}$ \\
\hline AST (GOT) & 27 & 5-34 / U/L \\
\hline Serum amylase & 47 & $25-125 / \mathrm{U} / \mathrm{L}$ \\
\hline D-bilirubin & $0.74 \Delta$ & $0.0-0.50 / \mathrm{mg} / \mathrm{dl}$ \\
\hline T-bilirubin & $2.05 \Delta$ & $0.2-1.2 / \mathrm{mg} / \mathrm{dl}$ \\
\hline Serum calcium & 9.6 & $8.4-10.2 / \mathrm{mg} / \mathrm{dl}$ \\
\hline Cholinesterase & 8267 & $4.000-12.600 / \mathrm{U} / \mathrm{l}$ \\
\hline Cholesterol & 113 & $0.0-199 / \mathrm{mg} / \mathrm{dl}$ \\
\hline CK & 58 & $28-168 / U / 1$ \\
\hline Serum creatinine & 1.02 & $0.57-1.11 / \mathrm{mg} / \mathrm{dl}$ \\
\hline Dldl & 54 & $0-130 \mathrm{mg} / \mathrm{dl}$ \\
\hline lonic calcium & $3.95 \nabla$ & $4.2-5.2 \mathrm{mg} / \mathrm{dl}$ \\
\hline GGT & 36 & $9-36 / U / 1$ \\
\hline Blood glucose & 94 & $65-111 / \mathrm{mg} / \mathrm{dl}$ \\
\hline Syderemia & 79 & $50-70 /$ ug/dl \\
\hline LDH & 204 & $125-243 /$ U/ \\
\hline Magnesium & 1.85 & $1.6-2.6 / \mathrm{mg} / \mathrm{dl}$ \\
\hline Total proteins & 7.9 & $6.48-8.3 / \mathrm{g} / \mathrm{dl}$ \\
\hline Triglycerides & 90 & $0-150 / \mathrm{mg} / \mathrm{dl}$ \\
\hline $\mathrm{HDL}$ & 41 & $40.0-60.0 / \mathrm{mg} / \mathrm{dl}$ \\
\hline Urea & 38.52 & $21.0-43.0 \mathrm{mg} / \mathrm{dl}$ \\
\hline Uric acid & $7.0 \wedge$ & $2.6-6.0 \mathrm{mg} / \mathrm{dl}$ \\
\hline CK-MB & $31 \Delta$ & $0-24 / U / 1$ \\
\hline
\end{tabular}

Table 1. Laboratory findings - biochemistry 


\section{INTERNAL MEDI}

Clinical cases

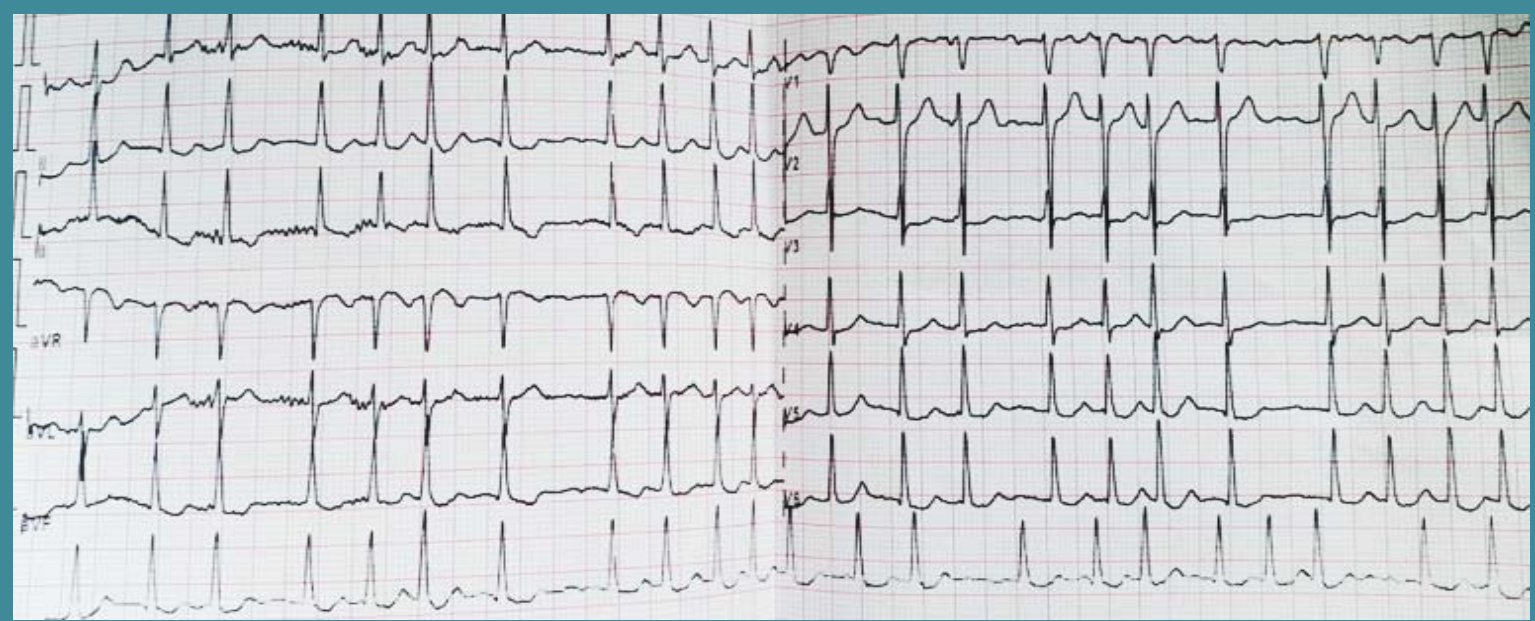

Figure 1. ECG before surgery - atrial fibrillation, 100/min, negative T wave in DIII

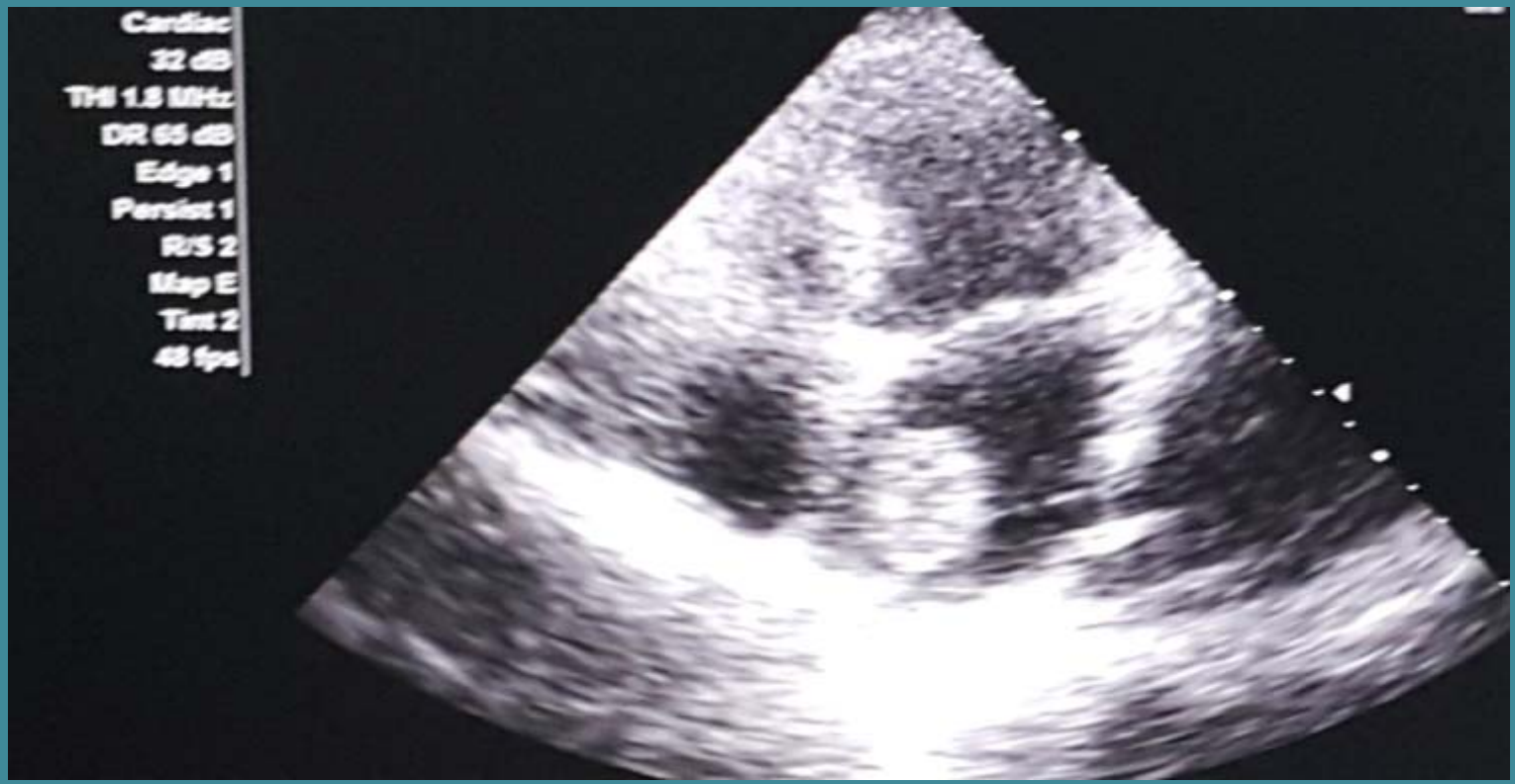

Figure 2. Transthoracic echocardiographic image in the apical 4-chamber view showing left atrial mass indicated by arrow 
mass $^{(4)}$. The 2-D cardiac transthoracic echography indicated the features of a atrial myxoma due to the fact that the mass was attached with a narrow stalk to the interatrial septum and was mobile during the cardiac cycles.

Left atrial thrombi are usually found in the left atrial appendage and the presence of the spontaneous atrial contrast echoes image is very characteristic. Myxomas are usually larger than thrombi ${ }^{(5)}$.If there are doubts regarding the size, the smooth contour or the connection with the interatrial septum at transesophageal echocardiography (TEE) or cardiac CT may give the final conclusion ${ }^{(6)}$. The presence of atrial fibrillation and mitral stenosis may favor the cardiac thrombi appearance. If the diagnosis remains uncertain a short cure of anticoagulation therapy can be initiated with periodic assessment of the cardiac mass.

The surgical option was adopted in our case since this is the most suitable curative option. The histopathological examination of the myxoma revealed fibrotic mass with myxoma-type cells.

The persistent issue is whether the initiation of anticoagulation therapy is properly or not. Thrombocytes reached 70.000 after the surgery and the sinus rhythm restored so the attitude was to leave only NSAID's along with beta blockers.

The long term follow up is crucial for discovering the recurrence of the cardiac tumors and should include a clinical examination and two-dimensional echocardiography ${ }^{(7)}$. Our patient was evaluated until now at 1 month, 3 months, 6 months after the surgery. The first visit revealed the fact that the sinusal rhythm was maintained and the thrombocytes values remained constant, so there was no changes in the treatment.

\begin{tabular}{|l|c|c|}
\hline \multicolumn{3}{|c|}{ ERITHROCYTE SEDIMENTATION RATE } \\
\hline VSH $1 \mathrm{~h}$ & 10 & $2-30 / \mathrm{mm} / \mathrm{h}$ \\
\hline VSH $2 \mathrm{~h}$ & 27 & $4-60 / \mathrm{mm} / \mathrm{h}$ \\
\hline
\end{tabular}

Table 2. Laboratory findings - ESR

\begin{tabular}{|c|c|c|}
\hline \multicolumn{3}{|c|}{ HEMOLEUCOGRAME } \\
\hline TEST & VALUE & NORMAL RANGES \\
\hline Wbc & 4.538 & $4.0-10.0 / 10^{\wedge} 3 / u L$ \\
\hline Neu\# & 2.807 & $2.4-6.5 / 10^{\wedge} 3 / \mathrm{uL}$ \\
\hline Lym\# & 1.393 & $1.2-3.4 / 10^{\wedge} 3 / \mathrm{uL}$ \\
\hline Mono\# & 0.234 & $0.1-0.6 / 10^{\wedge} 3 / \mathrm{uL}$ \\
\hline Eos\# & 0.046 & $0.0-0.6 / 10^{\wedge} 3 / \mathrm{uL}$ \\
\hline Baso\# & 0.057 & $0.0-0.2 / 10^{\wedge} 3 / \mathrm{uL}$ \\
\hline Neu $\%$ & 61.850 & $40-70 / \%$ \\
\hline Lym $\%$ & 30.700 & $20-45 / \%$ \\
\hline Mono\% & 5.167 & $2-8 / \%$ \\
\hline Eos $\%$ & $1.014 \nabla$ & $2.0-4.0 / \%$ \\
\hline Baso $\%$ & 1.261 & $0-2 / \%$ \\
\hline $\mathrm{Rbc}$ & $5.460 \wedge$ & $3.8-4.8 / 10^{\wedge} 3 / \mathrm{uL}$ \\
\hline $\mathrm{Hgb}$ & 14.610 & $12.0-15.0 \mathrm{G} / \mathrm{DL}$ \\
\hline Hct & $48.220 \wedge$ & $37-47 \%$ \\
\hline Mcv & 88.320 & $80-100 / f L$ \\
\hline Mch & $26.760 \nabla$ & $27-34 \%$ \\
\hline Mchc & $30.300 \nabla$ & $33.0-35.0 \mathrm{~g} / \mathrm{dL}$ \\
\hline $\mathrm{Rdw}$ & 12.760 & $11.6-16.5 / \%$ \\
\hline PIt & 80.000 & $150-450 / 10^{\wedge} 3 / \mathrm{uL}$ \\
\hline $\mathrm{Mpv}$ & $6.924 \nabla$ & $7.4-11.0 / \mathrm{fL}$ \\
\hline Pct & 0.058 & $0.158-0.425 / \%$ \\
\hline $\mathrm{Pdw}$ & $20.260 \nabla$ & $12.0-16.5$ \\
\hline
\end{tabular}

Table 3. Laboratory findings - complete blood count 


\section{INTERNAL MEDI}

Clinical cases

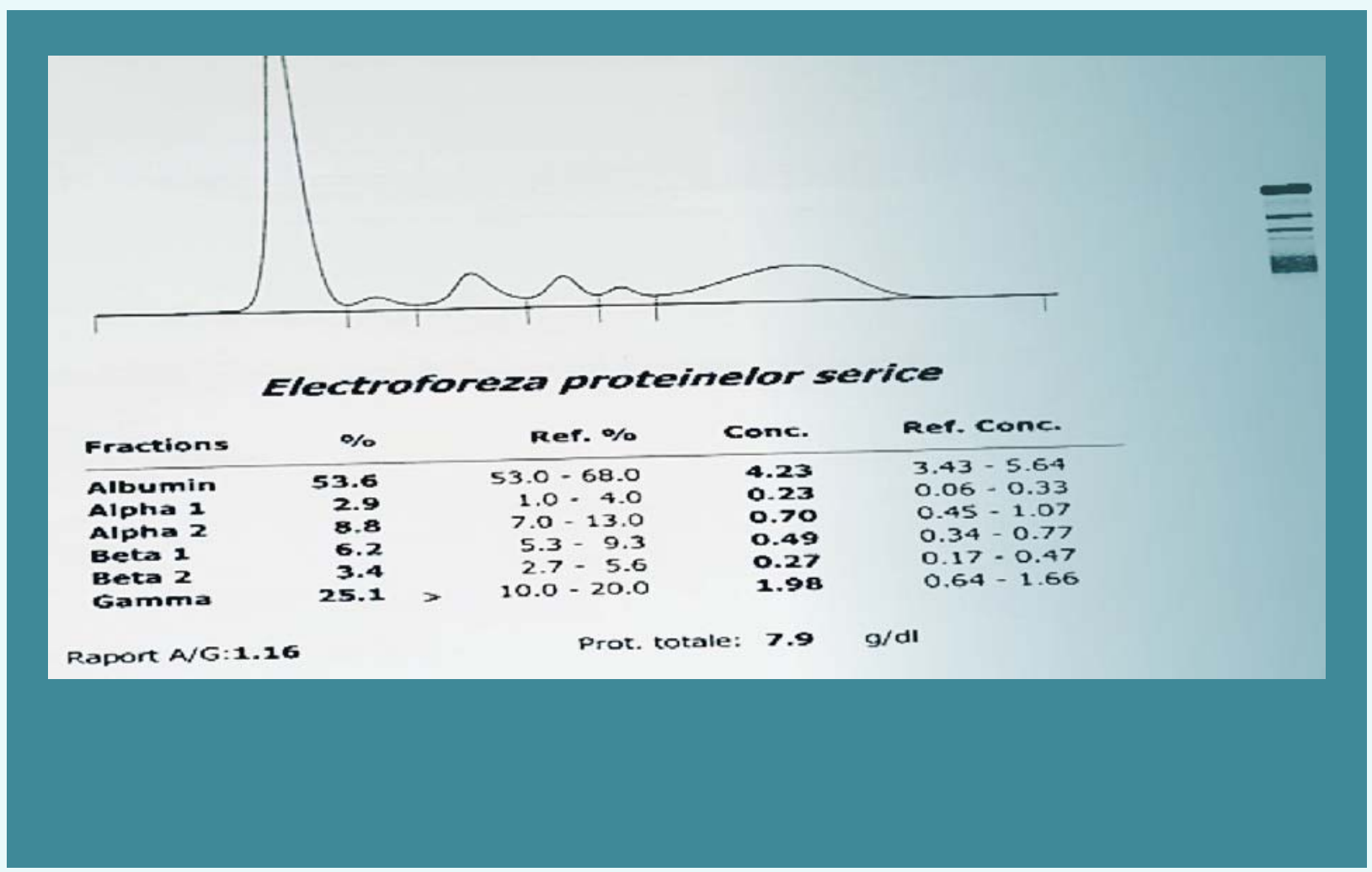

Figure 3. Proteins electrophoresis

\section{Conclusions}

The atrial myxomas may present with general manifestations or the complications involving embolic dissemination or atrioventricular orifice obstruction determining acute heart failure ${ }^{(8)}$.

Our case reveals the importance of the clinical judgement of the physician because the clinical context contains suggestive elements for atrial thrombosis, such as atrial fibrillation and atrial enlargement, but the transthoracic and transesophageal echocardiography reveals the features of an atrial myxoma. The interesting fact is the association of the thrombocytopenia that postpones the initiation of anticoagulation option. Also the removal of the tumor was benefic for solving the arrhythmia.

\section{References:}

1. Colucci WS, Schoen FJ. In: Primary tumors of the heart, chapter 49. Heart Disease: A textbook of Cardiovascular Medicine. 6th edition. Edited by Braunwald E, Zipes D, Libby P. Philadelphia, Pennsylvania, USA, W.B. Saunders 
Company 2001; 2: 1809-1819.

2. https://www.dermnetnz.org/topics/myxomasyndrome

3. Suraj Wasudeo Nagre, Mobile left atrial mass-clot or left atrial myxoma, J Med Oncl Ther 2016; 1 (3): 94-96.

4. Kyeong-Hee Jang, Dae-Hee Shin, Changkun Lee, JinKun Jang, Sangsig Cheong, San-Yong Yoo, Left Atrial Mass with Stalk: Thrombus or Myxoma?, J Cardiovasc Ultrasound. $2010 \mathrm{Dec}$; 18(4): 154-156.

5. Burke A, Jeudy J, Jr, Virmani R. Cardiac tumours: an update: Cardiac tumours. Heart. 2008;94:117-123.
6. Gabriel Dumitrasciuc, Marian Gaspar, Adina Ionac, Calin Jusca, Petre Deutsch, Lucian Petrescu, Bogdan MutVitcu, Stefan I. Dragulescu, Left atrial myxoma associated with coronary artery disease - uncommon challenge, TMJ 2004, Vol. 54, No. 4: 370-373.

7. Gaspar M, Laufer G, Antretter H, et al. Mixomul cardiac spectrul clinic variat care intarzie diagnosticul. TMJ 2002; 2: 63-65.

8. Stevens $L M$, Lapierre $H$, Pellerin $M$, et al. Atrial versus biatrial approaches for cardiac myxomas. Interactive Cardiovascular and Thoracic Surgery 2003; 2 :521-525. 